\title{
Morphometric Analysis of Sandran Drainage Basin (J \& K) using Geo-Spatial Technology
}

\author{
Aadil Manzoor Nanda, Pervez Ahmed, T. A. Kanth and Rafiq A. Hajam \\ Department of Geography \& Regional Development \\ University of Kashmir, J\&K, India \\ Email: aadilgeoku@gmail.com
}

\begin{abstract}
In the present study, morphometric analysis has been carried out using Geographical Information System (GIS) techniques to assess the geo-hydrological characteristics of Sandran drainage basin with an area of $318.25 \mathrm{~km}^{2}$ located in the south-eastern part of Anantnag district, Jammu and Kashmir, India. The basin is characterized by dendritic to sub-dendritic drainage pattern in the upper part of the catchment, and more or less parallel in the lower part. The analysis reveals that the total number and length of stream segments confirms the Horton's law. Calculated Circularity Ratio $\left(R_{c}\right)$ value of 0.27 and value of Elongation Ratio $\left(R_{e}\right) 0.41$ indicates that the basin is elongated in shape, having low discharge of runoff and relatively permeable subsoil condition. The value of Form Factor $\left(R_{f}\right), 0.26$, represents a flatter peak of flow for longer duration. Flood flows of such elongated basins are easier to manage than of the circular basin. The study further validates that the morphometric analysis based on GIS techniques is quite suitable and competent tool for geo- hydrological studies. These studies are very useful for rain water harvesting and watershed management.
\end{abstract}

Keywords: Morphometry, Linear parameters, Areal parameters, Drainage basin, GIS, Sandran stream.

\section{Introduction}

Morphometry is the measurement and mathematical analysis of the configuration of the earth's surface, shape and dimension of its landforms (Agarwal, 1998; Obi Reddy et al., 2002). Morphometric studies in the field of hydrology were first initiated by Horton (1940) and Strahler (1950). The morphometric analysis of the drainage basin and channel network play a vital role for understanding the geo-hydrological behavior of drainage basin and expresses the prevailing climate, geology, geomorphology, structural etc. antecedents of the catchment. The relationship between various drainage parameters and the aforesaid factors are well recognized by many workers (Horton, 1945; Strahler, 1957; Melton, 1958; Pakhmode, et al., 2003; Gangalakunta et al., 2004). The drainage basin analysis is important in any hydrological investigation like assessment of groundwater potential, groundwater management, pedology and environmental assessment etc. Hydrologists and geomorphologists have recognized that certain relations are most important between runoff characteristics, geographic and geomorphic characteristics of drainage basin systems. Various important hydrologic phenomenon's can be correlated with the physiographic characteristics of drainage basins such as size, shape, slope of drainage area, drainage density, size and length of the contributories etc. (Rastogi et al., 1976). Geology, relief and climate are the primary determinants of running water ecosystems functioning at the basin scale (Mesa, 
2006). Geographical Information System (GIS) techniques are now-a-days used for assessing various terrain and morphometric parameters of the drainage basins and watersheds, as they provide a flexible environment and a powerful tool for the manipulation and analysis of spatial information.

The objective of the present study is to analyze the linear and areal morphometric attributes of Sandran stream basin in south-eastern part of Anantnag district by using geospatial tools. This study gives an insight into the different geo-hydrological characteristics of the drainage basin.

\section{Study Area}

The Sandran drainage basin occupies the south eastern part of the Kashmir valley (Fig. 1) and is situated between $33^{0} 20^{\prime}$ to $34^{0} 15^{\prime}$ north latitude and $74^{0} 30^{\prime}$ to $75^{0} 15^{\prime}$ east longitude. The Sandran stream is the important right bank perennial tributary of the Jhelum River. Having its birth from the Satrashan springs (seven springs) on the gentler southern slopes of the Pir Panjal range of Kashmir Himalayas below the Kaukut peak, the river passes through a deep carved channel, studded with big boulders from its source to a point close to Vernag. It merges with the Jhelum a little above Khanabal near Anantnag town after traversing a course of about $52 \mathrm{kms}$ (Raza et al., 1978). Extending over a total catchment area of about $318.25 \mathrm{~km}^{2}$ (i.e., about 3 percent of the total drainage basin of Jhelum stream), it flows in the direction of north-west and irrigates most areas of Dooru Shahabad.

The study area is elongated in shape and has varied topography. The soils of the Sandran catchment belong to the groups of the brown forest soils, lacustrine (Karewa) soils and alluvial soils. Lithologically, the alluvium consists of blue, grey/silts and clay shales and sands of different textures and structures. The size of the grain varies from fine, medium to coarse. The valley possesses distinctive climatic characteristics because of its high altitude location and its geophysical setting, being enclosed on all sides by high mountain ranges. The valley is characterized by sub-Mediterranean type of climate with nearly 70 per cent of its annual precipitation concentrated in winter and spring months (Meher, 1971).

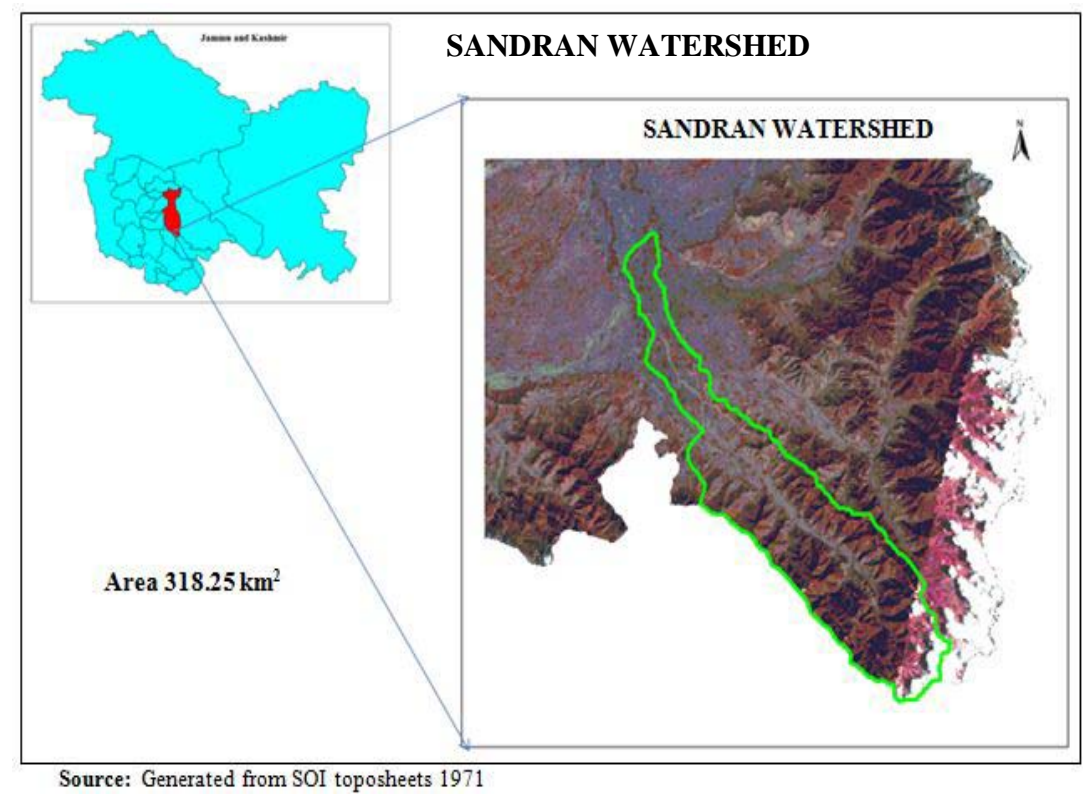

Fig. 1: Location map of the area. 
Open access e-Journal

Earth Science India, elSSN: $0974-8350$

Vol. 7 (II), April, 2014, pp. 55-66

http://www.earthscienceindia.info/

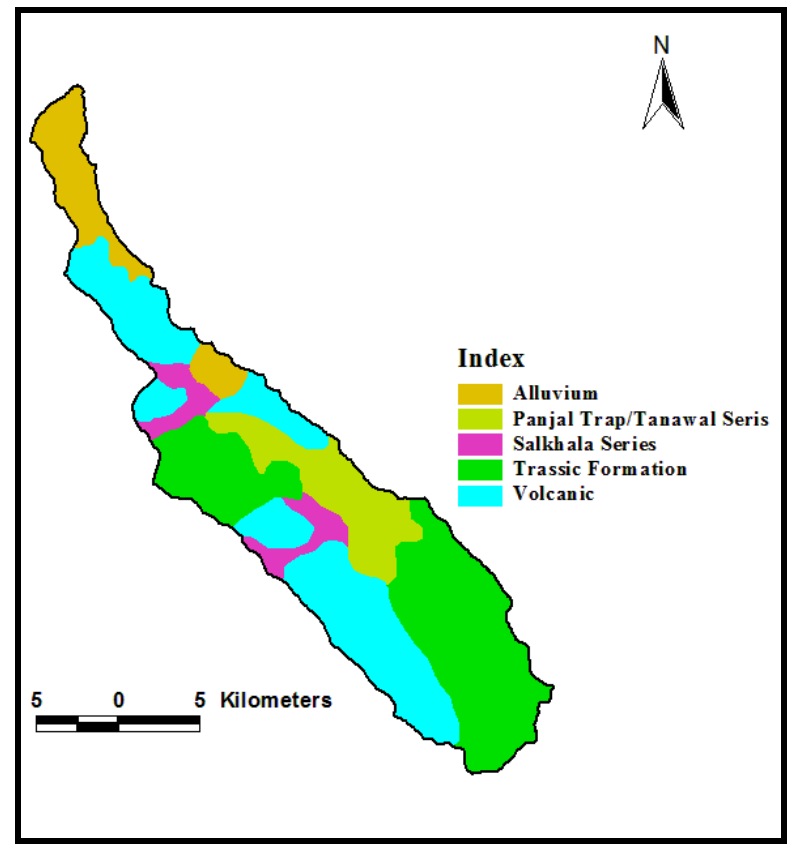

Fig. 2: Geology map of study area (after Geological Survey of India).

The study area "Sandran” has a very complex and rugged topography with very high relief and steep slopes. Geologically, it consists mainly of Alluvium, Panjal Trap, Salkhala Series and Triassic limestone (Fig. 2). Alluvium spreads over a large area than other formations. However, Triassic limestone is fully exposed at high-elevated areas and has undergone intensive tectonic deformation and weathering. The Triassic limestones are compact thinly bedded with frequent interstrata of black sandy and calcareous shales. The volcanics belong to the carboniferous fissure lava flows. The size of the rock grains varies from fine to medium. Lithologically, the alluvium consists of blue and grey clay, silts and sands of different texture and structure. The size of the grains varies from fine to coarse.

\section{Database and Methodology}

The entire study area is delineated from rectified, mosaiced SOI topographic maps of 1971 with No. 43 O/1, 2, 3, 6 \& 7 on 1:50,000 scale with the help of Arc-GIS 9.0 software assigning UTM, WGS 1984, 43N zone projection system. Morphometric analysis of a drainage system requires the delineation of all the existing streams. Digitization of the drainage basin was carried out for morphometric analysis in GIS environment using Arc GIS 9.0 software. The attributes were assigned to create the digital data base for drainage layer of the river basin. Various morphometric parameters such as linear aspects and aerial aspects of the drainage basin were computed. Digitization work was carried out for entire analysis of drainage morphometry. The different morphometric parameters have been determined as shown in Table-3. 


\section{Results and Discussion}

The study of basin morphometry relates basin and stream network geometries to the transmission of water and sediment through the basin. Systematic description of the geometry of a drainage basin and its stream channel requires measurement of linear aspects of the drainage network, areal aspects of the drainage basin, and relief (gradient) aspects of the channel network and contributing ground slopes (Strahler, 1964). In the present study, the morphometric analysis is carried out with respect to parameters like stream order, stream length, bifurcation ratio, stream length ratio, basin length, drainage density, stream frequency, elongation ratio, circularity ratio and form factor etc. using mathematical formulae as given in Table-3 and the results are summarized in Table-1 and 2. The properties of the stream networks are very important to study the landform making processes (Strahler and Strahler, 2002). Morphometric parameters such as relief, shape and length also influence basin discharge pattern strongly through their varying effects on lag time (Gregory and Walling, 1973).

The natural run-off is one of the most potent geomorphic agencies in shaping the landscape of an area. The land area that contributes water to the main stream through smaller ones forms its catchment area or the drainage basin. The arrangement of streams in a drainage system constitutes the drainage pattern, which in turn reflects mainly structural/ or lithologic controls of the underlying rocks (Eesterbrooks, 1969). The drainage pattern of Sandran Stream basin is dendritic in nature in the upper part of the catchment, and more or less parallel in the lower part.

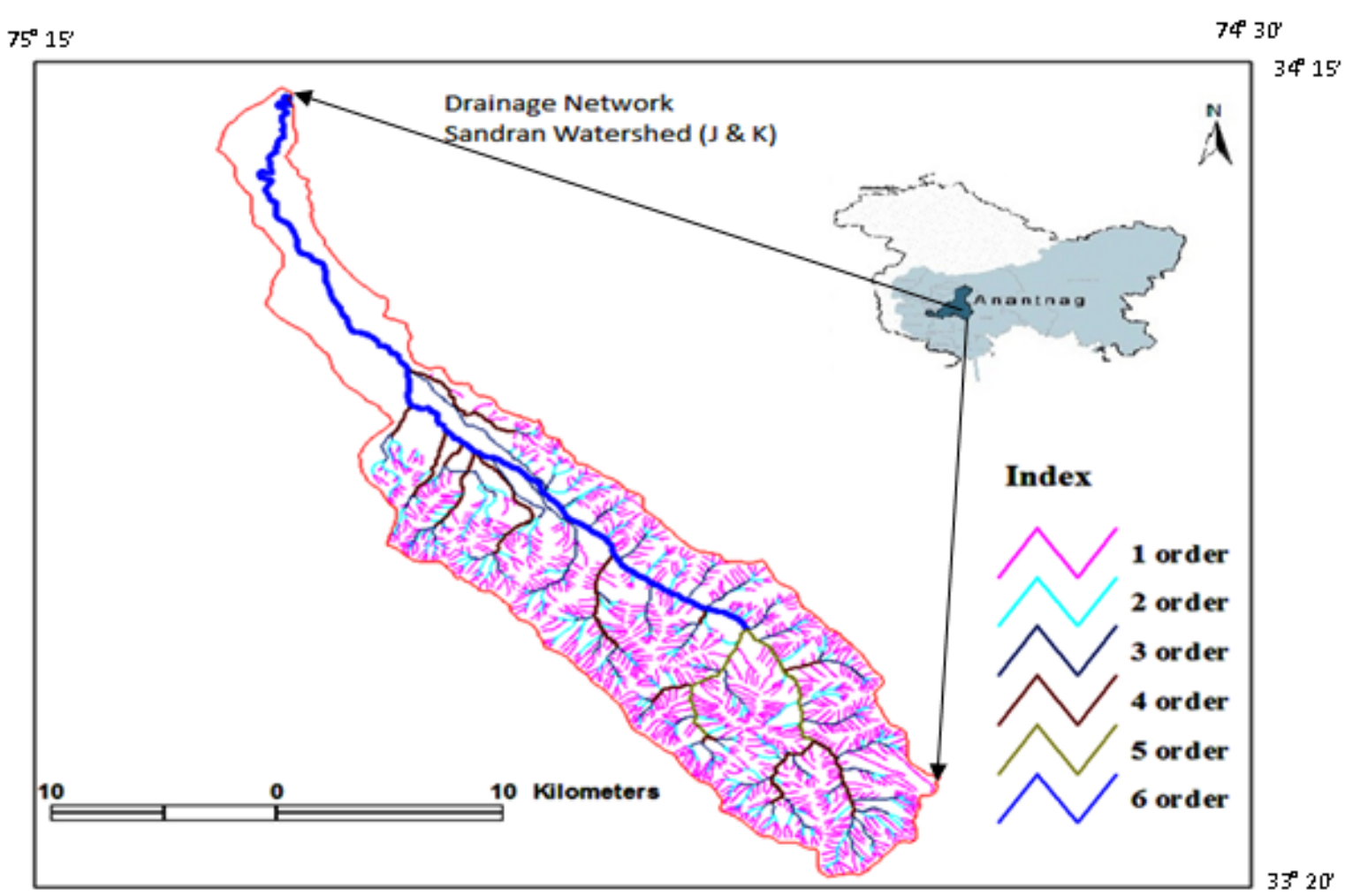

Fig. 3: Drainage map of study area. 
Open access e-Journal

Earth Science India, elSSN: $0974-8350$

Vol. 7 (II), April, 2014, pp. 55-66

http://www.earthscienceindia.info/

\section{Linear Morphometric Parameters}

\section{Stream Order:}

The designation of stream order is the first step in the drainage basin analysis. It is defined as a measure of the position of a stream in the hierarchy of tributaries (Leopord et al., 1969). In the study area 1300 streams linked with 6 orders of streams (Fig. 3) sprawled over an area of $318.25 \mathrm{~km}^{2}$. A perusal of Table-2 reveals that the Sandran Stream which is the trunk stream in Sandran drainage basin is of the sixth order. It is observed that there is a decrease in stream frequency as the stream order increases. First order streams constitute 77.54 per cent while second order streams constitute 15.77 per cent of the total number of streams. Third and fourth order streams constitute 5.07 per cent and 1.38 per cent of the total number of streams respectively while fifth and sixth order streams together constitute only 0.91 per cent of the total number of streams. Thus, the law of lower the order higher the number of streams is implied throughout the catchment.

\section{Bifurcation ratio $\left(\mathbf{R}_{\mathbf{b}}\right)$ :}

Bifurcation ratio is related to the branching pattern of a drainage network (Schumn, 1956). It is a dimensionless property and shows only a small variation for different regions with different environments except where powerful geological control dominates (Strahler, 1964).Values of $R_{b}$ typically range from the theoretical minimum of 3 to 5 for basins in which the geologic structures do not distort the drainage pattern (Strahler, 1964). From the Table-1, it is clear that the bifurcation ratio values for the Sandran drainage basin vary from 2.0 to 9.0 with the mean bifurcation ratio of 4.5 . The highest $R_{b}(9.00)$ is found between 4 th and $5^{\text {th }}$ order which indicates corresponding highest overland flow and discharge due to hilly hard rock formation associated with high slope configuration. This higher value of $\mathrm{R}_{\mathrm{b}}$ is the manifestation of the structural control in the roughly middle part of the basin area (where such drainage lines are dominant).

The mean bifurcation ratio, which is the average of bifurcation ratios of all orders, is 4.5. This relatively lower value of mean bifurcation ratio suggests the geological heterogeneity, higher permeability and_structural control in the area.

\section{Stream length $(\mathrm{L} \mu)$ :}

Stream length reveals surface runoff characteristics in the basin for hydrological interpretation. The stream segment lengths decreased with the increase in the stream order with the exception of the $6^{\text {th }}$ order stream whose length is greater than the total length of the $5^{\text {th }}$ order stream segments. From Table- 1 it is evident that the length of first order streams constitute 64.14 per cent of the total stream length with second order 14.37 per cent, third order 10.32 per cent, fourth order 5.04 per cent, fifth order 1.58 per cent and the sixth order 4.53 per cent. Generally higher the order, longer the length of streams is noticed in nature and off course it conforms to the Sandran drainage basin as well. These variations from general 
observation may be due to flowing of streams from high altitude, change in rock type and variation in slope and topography (Singh and Singh, 1997; Vittala et al., 2004).

Table-1: Linear morphometric parameters of the drainage network of Sandran Drainage Basin.

\begin{tabular}{|c|c|c|c|c|c|c|c|}
\hline $\begin{array}{l}\text { Stream } \\
\text { order } \\
(\mathrm{S} \mu)\end{array}$ & $\begin{array}{l}\text { Stream } \\
\text { number } \\
(\mathrm{N} \mu)\end{array}$ & $\begin{array}{l}\text { Bifurcation } \\
\text { ratio }\left(\mathbf{R}_{\mathbf{b}}\right)\end{array}$ & $\begin{array}{l}\text { Stream } \\
\text { length } \\
(\mathrm{L \mu})(\mathrm{kms})\end{array}$ & $\begin{array}{l}\text { Mean } \\
\text { stream } \\
\text { length }\left(L_{s m}\right) \\
\text { (kms) }\end{array}$ & $\begin{array}{l}\text { Cumulative } \\
\text { Mean stream } \\
\text { length }\left(L_{s m}\right)\end{array}$ & $\begin{array}{l}\text { Stream } \\
\text { length ratio } \\
\left(\mathbf{R}_{\mathrm{L}}\right)\end{array}$ & $\begin{array}{l}\text { Mean } \\
\text { bifurcation } \\
\text { ratio }\left(R_{b m}\right)\end{array}$ \\
\hline \multirow[t]{2}{*}{$1^{\text {st }}$} & $\begin{array}{l}1008 \\
(77.54)\end{array}$ & & $\begin{array}{l}594.72 \\
(64.14)\end{array}$ & 0.59 & 0.59 & & \multirow{11}{*}{4.5} \\
\hline & & 4.9 & & & & 1.10 & \\
\hline \multirow[t]{2}{*}{$2^{\text {nd }}$} & $\begin{array}{c}205 \\
(15.77)\end{array}$ & & $\begin{array}{l}133.25 \\
(14.37)\end{array}$ & 0.65 & 1.24 & & \\
\hline & & 3.1 & & & & 2.23 & \\
\hline \multirow[t]{2}{*}{$3^{\text {rd }}$} & $\begin{array}{c}66 \\
(5.07)\end{array}$ & & $\begin{array}{l}95.70 \\
(10.32)\end{array}$ & 1.45 & 2.69 & & \\
\hline & & 3.7 & & & & 1.79 & \\
\hline \multirow[t]{2}{*}{$4^{\text {th }}$} & $\begin{array}{c}18 \\
(1.38)\end{array}$ & & $\begin{array}{l}46.80 \\
(5.04)\end{array}$ & 2.60 & 5.29 & & \\
\hline & & 9.0 & & & & 2.82 & \\
\hline \multirow[t]{2}{*}{$5^{\text {th }}$} & $\begin{array}{c}2 \\
(0.15) \\
\end{array}$ & & $\begin{array}{l}14.66 \\
(1.58) \\
\end{array}$ & 7.33 & 12.62 & & \\
\hline & & 2.0 & & & & 5.72 & \\
\hline $6^{\text {th }}$ & $\begin{array}{c}1 \\
(0.076)\end{array}$ & & $\begin{array}{l}42 \\
(4.53)\end{array}$ & 42 & 54.62 & & \\
\hline Total & $\begin{array}{l}1,300 \\
(100) \\
\end{array}$ & & $\begin{array}{l}927.13 \\
(100) \\
\end{array}$ & & & & \\
\hline
\end{tabular}

Source: Computed from SOI toposheets on 1:50,000 scale, 1971. Note: Figures in parenthesis show Percentage stream length contributed by different stream orders.

\section{Mean stream length $\left(\mathbf{L}_{\mathrm{sm}}\right)$ :}

Mean stream length reveals the characteristic size of components of a drainage network and its contributing surfaces (Strahler, 1964). In the study area, it is noted that $\mathrm{L}_{\mathrm{sm}}$ varies from 0.59 to $42.0 \mathrm{~km}$ and its value for any given order is greater than that of the lower order and less than that of its next higher order in the whole drainage basin. It means that the number of contributing tributaries decreases continuously with increasing stream order and perhaps it applies to the volume of water as well.

\section{Stream Length Ratio $\left(\mathbf{R}_{\mathrm{L}}\right)$ :}

The stream length ratio has important relationship with surface flow and discharge and erosion stage of the basin (Horton, 1945). It is noticed that the $\mathrm{R}_{\mathrm{L}}$ between successive stream orders of the basin vary due to differences in slope and topographic conditions (Sudheer, 1986; Sreedevi, 1999). The values of $\mathrm{R}_{\mathrm{L}}$ vary haphazardly from 1.10 to 5.72. Since the Sandran stream basin shows changes in $\mathrm{R}_{\mathrm{L}}$ from one order to another, it is deduced that it is characterized by the late youth to early mature stage of geomorphic development (Singh and Singh, 1997). 
Open access e-Journal

Earth Science India, elSSN: $0974-8350$

Vol. 7 (II), April, 2014, pp. 55-66

http://www.earthscienceindia.info/

\section{Length of Overland Flow $\left(\mathrm{L}_{\mathrm{g}}\right)$ :}

$\mathrm{L}_{\mathrm{g}}$ is one of the most important independent variables affecting both hydrologic and physiographic development of drainage basins and relates reciprocally to the average slope of the channel and is quite synonymous with the length of sheet flow to a large extent. The length of overland flow depends primarily on the degree of relief fragmentation, and hence on the drainage density. In this study, the length of overland flow of the Sandran drainage basin is $0.17 \mathrm{Kms}$, which shows low surface runoff in the study area.

\section{Basin Perimeter (P):}

Basin perimeter is measured along the divides between basins and may be used as an indicator of basin size and shape Schumm (1956). The author has computed the basin perimeter by using Arc GIS-9.0 software, which is $121.21 \mathrm{Kms}(\mathrm{NIH}, 1998)$

\section{Basin Length $\left(\mathrm{L}_{\mathrm{b}}\right)$ or Valley Length $\left(\mathrm{L}_{\mathrm{v}}\right)$ :}

According to Gregory and Walling (1973), the $\mathrm{L}_{b}$ is the longest length of the basin, from the catchment to the point of confluence. The Sandran River meets the Jhelum at the point of confluence in the extreme north-northwest part of the study area. The length of the Sandran River basin is $34.63 \mathrm{~km}^{2}$, and is shown in Table- 1 .

\section{Areal Morphometric Parameters}

Area of a basin (A) and perimeter (P) are the important parameters in quantitative morphology. The area of the basin is defined as the total area projected upon a horizontal plane contributing to cumulate of all orders of a basin. Perimeter is the length of the boundary of the basin which can be drawn with the help of GIS software. Basin area directly affects the size of the storm hydrograph, the magnitudes of peak and mean runoff. It is interesting that the maximum flood discharge per unit area is inversely related to size (Chorley et al., 1957). The aerial aspects of the drainage basin such as basin area (A) drainage density $\left(D_{d}\right)$, stream frequency $\left(F_{s}\right)$, texture ratio $\left(R_{t}\right)$, elongation ratio $\left(R_{e}\right)$, circularity ratio $\left(R_{c}\right)$ and form factor ratio $\left(R_{f}\right)$ were calculated and results have been given in Table- 2 .

Table-2: Areal Morphometric parameters of the drainage network of Sandran Drainage Basin. (Computed from SOI toposheets on 1:50,000 scale, 1971)

\begin{tabular}{|l|l|l|}
\hline S .No. & Parameter & Calculated Value \\
\hline 1 & Drainage Area $(A)$ & $318.25 \mathrm{~km}^{2}$ \\
\hline 2 & Drainage Density $\left(\mathrm{D}_{\mathrm{d}}\right)$ & $2.91 \mathrm{~km} / \mathrm{km}^{2}$ \\
\hline 3 & Drainage Frequency $\left(\mathrm{F}_{\mathrm{s}}\right)$ & $4.08 / \mathrm{km}^{2}$ \\
\hline 4 & Drainage Texture $\left(\mathrm{D}_{\mathrm{f}}\right)$ & $8.31-0.008$ \\
\hline 5 & Form Factor Ratio $\left(\mathrm{R}_{\mathrm{f}}\right)$ & 0.26 \\
\hline 6 & Elongation Ratio $\left(\mathrm{R}_{\mathrm{e}}\right)$ & 0.41 \\
\hline 7 & Circularity Ratio $\left(\mathrm{R}_{\mathrm{c}}\right)$ & 0.27 \\
\hline
\end{tabular}




\section{Drainage Area (A):}

The drainage area is defined as a collecting area from which water would go to a stream or river. The boundary of the area is determined by the ridge separating water flowing in opposite directions. The area of the basin was computed by converting the merged georeferenced and rectified SOI toposheets of 1971 on scale 1:50,000 of the basin into polygon form. The total area of the basin is found to be $318.25 \mathrm{~km}^{2}$.

\section{Drainage Density $\left(\mathbf{D}_{\mathrm{d}}\right)$ :}

The drainage density is an important indicator of the linear scale of landform element in stream eroded topography and is an expression of the closeness of spacing of channels (Horton, 1932). The measurement of $D_{d}$ is a useful numerical measure of landscape dissection and runoff potential (Chorley, 1969). On the one hand, the $D_{d}$ is a result of interacting factors controlling the surface runoff; on the other hand, it is itself influencing the output of water and sediment from the drainage basin (Ozdemir and Bird, 2009). $\mathrm{D}_{\mathrm{d}}$ is known to vary with climate and vegetation (Moglen et al., 1998), soil and rock properties (Kelson and Wells, 1989), relief (Oguchi, 1997) and landscape evolution processes. The $\mathrm{D}_{\mathrm{d}}$ of the Sandran drainage basin is $2.91 \mathrm{~km} / \mathrm{km}^{2}$. The drainage density in the study area being relatively low (Table -2) indicates clearly that the region has permeable subsoil, relatively dense vegetation cover and medium relative relief (Nag, 1998).

\section{Drainage Frequency $\left(F_{s}\right)$ :}

The stream frequency $\left(\mathrm{F}_{\mathrm{s}}\right)$ or channel frequency or drainage frequency of the whole basin is $4.08 / \mathrm{km}^{2}$, shown in Table-2. It mainly depends on the lithology of the basin and reflects the texture of the drainage network. It is an index of the various stages of landscape evolution. The occurrence of stream segments depends on the nature and structure of rocks, vegetation cover, nature and amount of rainfall and soil permeability. The greater the drainage density and stream frequency in a basin, the runoff is faster, and therefore, flooding is more likely in basins with a high drainage and stream frequency (Kale and Gupta, 2001).

\section{Drainage Texture $\left(D_{t}\right)$ :}

The drainage texture is considered as one of the important concept of geomorphology which shows the relative spacing of the drainage lines (Chorley et al, 1957). In the present study, the drainage texture values were found as 8.31 ( $1^{\text {st }}$ order streams $), 1.65$ ( $2^{\text {nd }}$ order streams), 0.54 ( $3^{\text {rd }}$ order streams), 0.14 ( $4^{\text {th }}$ order streams), 0.016 ( $5^{\text {th }}$ order streams) and 0.008 ( $^{\text {th }}$ order stream). Low drainage density leads to coarse drainage texture while high drainage density leads to fine drainage texture (Smith, 1939). So it is clear that the drainage texture values (Table-2) are variable and suggests that the study area falls into very coarse to coarse texture category and indicates good permeability of sub-surface material in the study area except the first order streams.

\section{Form Factor Ratio $\left(\mathbf{R}_{\mathrm{f}}\right)$ :}

Quantitative expression of drainage basin outline form was made by Horton (1932) through a form factor ratio $\left(\mathrm{R}_{\mathrm{f}}\right)$. The form factor value of the basin is low, 0.26 which represents elongated shape. The elongated basin with low form factor indicates that the basin 
Open access e-Journal

Earth Science India, elSSN: $0974-8350$

Vol. 7 (II), April, 2014, pp. 55-66

http://www.earthscienceindia.info/

will have a flatter peak of flow for longer duration. Flood flows of such elongated basins are easier to manage than of the circular basin (Christopher et al., 2010).

\section{Elongation Ratio $\left(\mathbf{R}_{\mathbf{e}}\right)$ :}

Schumm (1956) defined elongation ratio $\left(R_{e}\right)$ as the ratio of diameter of a circle of the same area as the basin to the maximum basin length. It is a very significant index in the analysis of basin shape which helps to give an idea about the hydrological character of a drainage basin. The value $R_{e}$ in the study area was found to be 0.41 indicating moderate relative relief of the terrain and elongated shape of the drainage basin.

\section{Circularity Ratio $\left(\mathbf{R}_{\mathbf{c}}\right)$ :}

The circularity ratio $\left(R_{c}\right)$ is affected by the lithological character of the basin. The ratio is more influenced by length, frequency $\left(\mathrm{F}_{\mathrm{s}}\right)$, and gradient of streams of various orders rather than slope conditions and drainage pattern of the basin. The calculated $R_{c}$ value for the study area is 0.27 which indicates that the drainage basin is elongated shape and is characterized by moderate relative relief.

\section{Conclusion}

The drainage basin is being frequently selected as a unit of geo-hydrological studies because of its topographic and geo-hydrological unity. GIS softwares have proved to be of the immense utility in the Linear and Areal morphometric studies of the drainage basins. Based on the drainage orders, the Sandran Basin has been classified as sixth order basin. The mean $\mathrm{R}_{\mathrm{b}}$ indicates that the drainage pattern is not much influenced by geological structures. Drainage density $\left(D_{d}\right)$ and stream frequency $\left(F_{s}\right)$ are the most useful criterion for the morphometric classification of drainage basins which certainly control the runoff pattern, sediment yield and other hydrological parameters of the drainage basin. The $D_{d}$ and $D_{t}$ of the basin reveal that the nature of subsurface strata varies from moderately permeable to permeable. This is a characteristic feature of drainage basin having $D_{t}$ varying from fine to course as the texture values are 8.31-0.008. The study reveals that the drainage areas of the basin are passing through an early mature stage of the fluvial geomorphic cycle. Lower order streams mostly dominate the basin. The developments of stream segments in the basin area are more or less affected by rainfall. $R_{c}, R_{f}$ and $R_{e}$ show the elongated shape of the basin, having low discharge of runoff and medium relief of the terrain. It is noticed that stream segments up to $3^{\text {rd }}$ order traverse parts of the high altitudinal zones with high relative relief, which are characterized by steep slopes, while the $4^{\text {th }}, 5^{\text {th }}$ and $6^{\text {th }}$ order stream segments occur in comparatively moderate relief areas wherein maximum infiltration of runoff occurs; these are important locations for constructing check dams. The results show that the area bears favorable condition and good water bearing properties that could be helpful for groundwater exploration. 
Acknowledgement: Authors wish to express their appreciation and gratitude towards Mr. Parvaiz A. Teli, Mr. Zahoor-ul-Hassan, Mr. Zahoor A. Nengroo, Jahangeer A. Parry and Arif H. Shah, Research Scholars of the Department of Geography, University of Kashmir, for their helpful inputs.

Table- 3: Morphometric parameters with formulae.

\begin{tabular}{|c|c|c|c|}
\hline S. No. & Parameters & Formula & Reference \\
\hline 1 & \multicolumn{3}{|c|}{ Linear Morphometric parameters } \\
\hline 1.1 & Stream Order $(\mathrm{S} \mu)$ & Hierarchical rank & Strahler (1964) \\
\hline 1.2 & Bifurcation Ratio $\left(\mathrm{R}_{\mathrm{b}}\right)$ & $\begin{array}{l}R_{b}=N \mu / N \mu+1 \\
W h e r e, R b=\text { Bifurcation ratio, } \\
N \mu=\text { No. of stream segments of a given order and } \\
N \mu+1=\text { No. of stream segments of next higher order. }\end{array}$ & Schumn (1956) \\
\hline 1.3 & $\begin{array}{l}\text { Mean } \\
\left(\mathrm{R}_{\mathrm{bm}}\right)\end{array}$ & $\mathrm{R}_{\mathrm{bm}}=$ Average of bifurcation ratios of all orders & Strahler (1964) \\
\hline 1.4 & Stream Length $(\mathrm{L} \mu)$ & Length of the stream (kilometers) & Horton (1945) \\
\hline 1.5 & Mean Stream Length $\left(\mathrm{L}_{\mathrm{sm}}\right)$ & $\begin{array}{l}\mathrm{L}_{\mathrm{sm}}=\mathrm{L} \mu / \mathrm{N} \mu \\
\text { Where, } \mathrm{L} \mu=\text { Total stream length of order ' } \mu \text { ' } \\
\mathrm{N} \mu=\text { Total no. of stream segments of order ' } \mu \text { ' }\end{array}$ & Strahler (1964) \\
\hline 1.6 & Stream Length Ratio $\left(\mathrm{R}_{\mathrm{L}}\right)$ & $\begin{array}{l}R_{L}=L_{s m} / L_{s m}-1 \\
\text { Where, } L_{s m}=\text { Mean stream length of a given order and } \\
L_{s m}-1=\text { Mean stream length of next lower order }\end{array}$ & Horton (1945) \\
\hline 1.7 & $\begin{array}{l}\text { Length of Overland Flow } \\
\left(L_{g}\right)\end{array}$ & $\begin{array}{l}\mathrm{L}_{\mathrm{g}}=1 / 2 \mathrm{D} \mathrm{Km} \\
\text { Where, } \mathrm{D}=\text { Drainage density }\left(\mathrm{Km} / \mathrm{Km}^{2}\right)\end{array}$ & Horton (1945) \\
\hline 1.8 & Basin Perimeter $(\mathrm{P})$ & $\begin{array}{l}\mathrm{P}=\text { Outer boundary of drainage basin measured in } \\
\text { kilometers. }\end{array}$ & Schumm (1956) \\
\hline 1.9 & Basin Length $\left(\mathrm{L}_{b}\right)$ & $\mathrm{L}_{\mathrm{b}}=1.312 * \mathrm{~A}^{0.568}$ & $\begin{array}{l}\text { Gregory and } \\
\text { Walling (1973) }\end{array}$ \\
\hline 2 & & Ireal Morphometric parameters & \\
\hline 2.1 & Basin Area (A) & $\begin{array}{l}\text { Area from which water drains to a common stream } \\
\text { and boundary determined by opposite ridges. }\end{array}$ & Strahler (1969) \\
\hline 2.2 & Drainage Density $\left(\mathrm{D}_{\mathrm{d}}\right)$ & $\begin{array}{l}D_{d}=L \mu / A \\
\text { Where, Dd = Drainage density }\left(\mathrm{Km} / \mathrm{Km}^{2}\right) \\
\mathrm{L} \mu=\text { Total stream length of all orders and } \\
\mathrm{A}=\text { Area of the basin }\left(\mathrm{Km}^{2}\right)\end{array}$ & Horton (1932) \\
\hline 2.3 & Drainage Frequency $\left(\mathrm{F}_{\mathrm{s}}\right)$ & $\begin{array}{l}F_{s}=N \mu / A \\
W h e r e, F_{s}=\text { Drainage frequency. } \\
N \mu=\text { Total no. of streams of all orders and } \\
A=\text { Area of the basin }\left(\mathrm{Km}^{2}\right)\end{array}$ & Horton (1932) \\
\hline 2.4 & Drainage Texture $\left(\mathrm{D}_{\mathrm{t}}\right)$ & $\begin{array}{l}D_{t}=N \mu / P \\
\text { Where, } N \mu=\text { No. of streams in a given order and } P= \\
\text { Perimeter }(\mathrm{Kms})\end{array}$ & $\begin{array}{l}\text { Smith (1950) \& } \\
\text { Horton (1945) }\end{array}$ \\
\hline 2.5 & Form Factor Ratio $\left(\mathrm{R}_{\mathrm{f}}\right)$ & $\begin{array}{l}\mathrm{R}_{\mathrm{f}}=\mathrm{A} / \mathrm{L}_{\mathrm{b}}{ }^{2} \\
\text { Where, } \mathrm{A}=\text { Area of the basin and } \\
\mathrm{L}_{\mathrm{b}}=(\text { Maximum) basin length }\end{array}$ & Horton (1932) \\
\hline 2.6 & Elongation Ratio $\left(\mathrm{R}_{\mathrm{e}}\right)$ & $\begin{array}{l}\mathrm{R}_{\mathrm{e}}=\sqrt{\mathrm{A}} / \pi / \mathrm{L}_{\mathrm{b}} \\
\text { Where, } \mathrm{A}=\text { Area of the Basin }\left(\mathrm{Km}^{2}\right) \\
\mathrm{L}_{\mathrm{b}}=\text { Maximum Basin length }(\mathrm{Km})\end{array}$ & Schumm (1956) \\
\hline 2.7 & Circularity Ratio $\left(\mathrm{R}_{\mathrm{c}}\right)$ & $\begin{array}{l}\mathrm{R}_{\mathrm{C}}=4 \pi \mathrm{A} / \mathrm{P}^{2} \\
\text { Where, } \mathrm{A}=\text { Basin Area }\left(\mathrm{Km}^{2}\right) \text { and } \\
\mathrm{P}=\text { Perimeter of the basin }(\mathrm{Km}) \\
\text { Or } \mathrm{R}_{\mathrm{c}}=\mathrm{A} / \mathrm{A}_{\mathrm{c}} \\
\text { Where, } \mathrm{A}=\text { Basin Area }\left(\mathrm{Km}^{2}\right) \text { and } \\
\mathrm{A}_{\mathrm{c}}=\text { area of a circle having the same perimeter as the } \\
\text { basin }\end{array}$ & Miller (1953) \\
\hline
\end{tabular}


Open access e-Journal

Earth Science India, elSSN: $0974-8350$

Vol. 7 (II), April, 2014, pp. 55-66

http://www.earthscienceindia.info/

\section{References}

Agarwal, C. S. (1998) Study of drainage pattern through aerial data in Naugarh area of Varanasi district, U.P. Jour. Indian Soc. Remote Sensing, v. 26, pp. 169-175.

Chorley, R.J., Donald Malm, E.G., and Pogorzelski, H.A. (1957) A new standard for estimating drainage basin shape. Amer. Jour. Sci., v. 255, pp. 138-141.

Chorley, R. J. (1969) Introduction to physical hydrology. Methuen and Co. Ltd., Suffolk, 211p.

Christopher, O., Idown A. O. and Olugbenga A. S. (2010) Hydrological analysis of Onitsha North East drainage basin using Geoinformatic Techniques. World Applied Science Journal, v. 11 (10), pp. 1297- 1302.

Eesterbrooks, D. (1969) Principles of geomorphology. NY: McGraw-Hill Inc. pp. 72-77.

Gangalakunta, P., Amal, K. and Kothiram, S. (2004) Drainage morphometry and its influence on landform characteristics in a basaltic terrain, Central India- a remote sensing and GIS approach. Inter. Jour. Appl. Earth and Geoinformation, v. 6, pp. 1-16.

Horton, R. E. (1932) Drainage basin characteristics. Am. Geophys. Union, Trans., v. 13, pp. 348- 352.

Horton, R. E. (1945) Erosional development of streams and their drainage basins: Hydrophysical approach to quantitative morphology. Geol. Soc. Am. Bull, v. 56, pp., 275-370.

Kelson, K. I. and Wells, S. G. (1989) Geologic influences on fluvial hydrology and bed load transport in small mountainous watersheds, northern New Mexico, USA. Earth Surf. Processes Landforms, v. 14, pp. 671-690.

Kale, V. S. and Gupta, A. (2001) Introduction to Geomorphology. Rawat Publishers, Delhi, pp. 84-86

Leopord, L. B., Wolman, M. G. and Miller J. P. (1969) Fluvial processes in geomorphology. WH Freeman and Company; San Francisco and London, pp. 4-9.

Meher, V. M. (1971) The climate of Srinagar and its variability. Geographical Review of India, v. 33, pp. 1-14.

Melton, M.A. (1958) Correlation structure of morphometric properties of drainage system and their controlling agents. Jour. Geol., v. 66, pp. 442-460.

Moglen, G. E., Eltahir, E. A. and Bras, R. L. (1998) On the sensitivity of drainage density to climate change. Water Resour. Res., v. 34, pp. 855-862.

Mesa, L. M. (2006) Morphometric analysis of a subtropical Andean basin (Tucumam, Argentina). Environmental Geology, v.50, pp.1235-1242.

Nag, S. K. (1998) Morphometric analysis using remote sensing techniques in the Chaka sub-basin, Purulia district, West Bengal. Jour. Indian Soc. Remote Sensing, v. 26, pp. 69-76.

National Institute of Hydrology (1998) Representative Basin Studies: Morphometric Analysis of Suddagedda Basin, Andhra Pradesh. CS(AR)-24/97-98, NIH, Roorkee.

Oguchi, T. (1997) Drainage density and relative relief in humid steep mountains with frequent slope failure. Earth Surf. Processes Landforms, v. 22, pp. 107-120.

Obi Reddy, G. E., Maji, A. K. and Gajbhiye, K. S. (2002) GIS for morphometric analysis of drainage basins. GIS India, v. 11, pp. 9-14.

Ozdemir, H. and Bird, D. (2009) Evaluation of morphometric parameters of drainage networks derived from topographic maps and DEM in point of floods. Environmental Geol., v. 56, pp. 1405-1415.

Pakhmode, V., Kulkarni, H., and Deolankar, S.B. (2003) Hydrological drainage analysis in watershed programme planning: A case study from the Deccan basalt, India. Hydrogeology Journal, v. 11, pp. 595 $-604$.

Raza, M., Ahmed, A. and Mohammad, A. (1978). The valley of Kashmir- a geographical interpretation, Vol. (I) The land. Vikas publishing house, New Delhi, pp. 220-223

Smith, G.H. (1939) The Morphometry of Ohio: The Average Slope of the Land (abstract). Annals of the Assoc. of American Geographers, v. 29, pp. 94.

Schumn, S. A. (1956) Evolution of drainage systems and slopes in badlands at Perth Amboy, New Jersey. Geol. Soc., Am. Bull., v. 67, pp. 597-646.

Strahler, A. N. (1957) Quantitative analysis of watershed geomorphology. Trans. Am. Geophys. Union, v 38, pp. 913-920.

Strahler, A. N. (1964) Quantitative geomorphology of drainage basins and channel networks. In: V. T. Chow (ed.), Handbook of applied hydrology. McGraw Hill Book Company, New York, pp. 4-11. 
Schmid, B. H. (1997) Critical rainfall duration for overland flow an infiltrating plane surface. Journal of Hydrology, v. 193, pp. 45-60.

Singh, S. and Singh, M.C. (1997) Morphometric analysis of Kanhar river basin. National Geographical J. of lndia, v. 43, pp. 31-43.

Strahler, A.N. and Strahler, A.H. (2002) A Textbook of Physical Geography. John Wiley and Sons, New York, $285 \mathrm{p}$.

Vittala, S., Govindaiah, S. and Honne, G. H. (2004) Morphometric analysis of sub-watersheds in the Pavagada area of Tumkur district, South India using remote sensing and GIS techniques. Jour. Indian Soc. Remote Sensing, v. 32, pp. 351-362.

Zavoiance I. (1985) Morphometry of Drainage Basins. (Developments in Water Science, 20) Elsevier Science, pp. 104-105.

(Received: 25.01.2013; Accepted: 15.03.2014) 